\title{
Sociocultural descriptions of febrile syndromes in rural areas of Urabá, Colombia: An exploration of "tick fever"
}

\author{
I ${ }^{1}$ Juan Carlos Quintero Vélez, ${ }^{2}$ Javier Mignone, ${ }^{3}$ Lisardo Osorio Quintero, \\ ${ }^{4}$ Carlos Rojas Arbeláez I
}

Abstract: Introduction: In 2006 and 2008 there were two lethal outbreaks of rickettsioses in the rural areas of Urabá, characterized by the lack of immediate diagnosis and antibiotic treatment. Objective: Describe sociocultural aspects about knowledge, attitudes and practices in relation to febrile syndromes and "tick fever" in rural areas of Urabá. Materials and methods: We conducted an exploratory study using knowledge, attitudes, and practices questionnaires and semi-structured interviews about febrile syndromes and "tick fever". We surveyed 246 heads of households and interviewed nine individuals. Results: We observed that people tended to identify febrile syndromes with signs and clinical symptoms of dengue, malaria, leptospirosis and rickettsioses. A considerable proportion of individuals (32.93\%) knew very little about "tick fever", thinking that is was transmitted by mosquitos. They mentioned intestinal parasitoids, malaria, dengue, and "evil eye" among the causes of febrile syndromes. "Tick fever" is linked by its name to the bite of the tick. Furthermore, the treatments for febrile syndromes mentioned by interviewees are associated to those commonly used in western medicine and medicinal plants. Conclusions: There is a need for educational programs in rural areas, to raise awareness about these potential lethal conditions that can be effectively treated.

> Keywords: KAP survey; rickettsioses; tick fever; reservoir.

\author{
${ }^{1}$ Grupo de Investigación Ciencias \\ Veterinarias Centauro, Universidad \\ de Antioquia. Medellin, Colombia \\ (juan.quintero@udea.edu.co). \\ ORCID: 0000-0001-7356-7751.

\footnotetext{
2 Department of Community Health Sciences, The University of Manitoba. Winnipeg, Canada (javier.mignone@umanitoba.ca). ORCID: 0000-0001-7248-9341.

${ }^{3}$ Grupo de Investigación Salud y Ambiente, Universidad de Antioquia. Medellin, Colombia (lisardo.osorio@udea.edu.co). ORCID: 0000-0003-0496-6665.

${ }^{4}$ Grupo de Epidemiología, Universidad de Antioquia. Medellin, Colombia (carlos. rojas@udea.edu.co).
} \\ ORCID: 0000-0002-1906-6048.
}

Received: 27/10/2018 Approved: 11/06/2019 


\section{Introduction}

Febrile syndromes are frequent among the population of Urabá, Antioquia, particularly in the rural areas (ARBOLEDA et al., 2012; YUSTI; ARBOLEDA; AGUDELO-FLÓREZ, 2012; VILLAR et al., 2015). Among other illnesses, the most frequently treated in both rural and urban health centres are dengue and malaria (ARBOLEDA et al., 2012; ARROYAVE et al., 2013; VILLAR et al., 2015). Due to the high frequency of febrile syndromes related to these two diseases, health care professionals and the community members associate all febrile syndromes with these diseases. As such, other causes of febrile syndromes tend to be forgotten or ignored (SUÁREZ et al., 2008).

Rickettsioses is caused by the infection of the bacteria of the Rickettsia genus that is transmitted by fleas, lice, mites and ticks (GILLESPIE et al., 2008). In Colombia, outbreaks have mostly occurred in the center of the country and its Atlantic coast by agents such as Rickettsia rickettsii that are transmitted by ticks (ACOSTA et al., 2006; HIDALGO et al., 2007, 2011; GARCÍA PACHECO et al., 2008). Since the 1930's, when there was a high mortality outbreak of rickettsiosis in Tobía, Cundinamarca, the disease has been known as "Fever of Tobía" (PATIÑO; AFANADOR; PAUL, 1937).

After this outbreak, between 2006 and 2008 there were three outbreaks in the departments of de Antioquia and Córdoba, causing the death of approximately 15 people. In the locality of Las Changas, municipality of Necoclí, there was an outbreak in 2006 with 35\% (5/14) lethality. In 2007 an outbreak occurred in the municipality of Córdoba with 54.5\% (6/11) lethality. In 2008 in the locality of Alto de Mulatos, Turbo, there was an outbreak with 28\% (4/14) lethality (ACOSTA et al., 2006; GARCÍA PACHECO et al., 2008; HIDALGO et al., 2011). These outbreaks created a partial alarm that started epidemiological surveillance of febrile syndromes in the area. Fevers of any type were surveilled and other lethal causes were diagnosed, among them leptospirosis (GARCÍA PACHECO et al., 2008).

A study that took place after the outbreaks identified six cases of rickettsiosis in the same area of Urabá. These findings evidenced the lack of surveillance of rickettsiosis in Colombia, given that the cases were found due to the study and not because there had been presumptions of diagnosing this disease (QUINTERO et al., 2013). In the hospitals of the region, surveillance of entities that cause febrile syndromes are 
done and are classified as fevers of dengue, salmonellosis, leptospirosis, and more recently chikungunya and zika. However, those that are not able to be diagnosed are classified as non-specified fevers, thus clinical cases remain without diagnosis or effective treatment (VALBUENA, 2007).

The genus Rickettsia received its name in honor of Howard Taylor Ricketts, who was the first to describe the causal agent in the Rocky Mountains of the United States (RICKETTS, 1909). The name "rickettsiosis" is mostly known in the scientific world, but is difficult to depict in the rural areas of Colombia, including where lethal cases have occurred. One of the most usual depictions, that is frequently associated with domestic animals, is "tick fever", name that due to its representation with the vector is more understandable in rural communities (SUÁREZ et al., 2008).

In addition to the lethal cases that have occurred in these rural areas, there is evidence in the localities of Las Changas and Alto de Mulatos of the prevalence of circulation of antibodies for rickettsia at different links of the cycle; wild animals and people (QUINTERO et al., 2013; LONDOÑO et al., 2017). Consequently, the study aimed to provide a sociocultural description of perceptions, knowledge, attitudes and practices of febrile syndromes and "tick fever" in areas where historically there have been lethal outbreaks of rickettsiosis.

\section{Materials y methods}

\section{Location}

The study took place in the localities of Alto de Mulatos $\left(8^{\circ} 08^{\prime} 12.5^{\prime \prime} \mathrm{N}\right.$ $\left.76^{\circ} 33^{\prime} 01.7^{\prime \prime W}\right)$ and Las Changas ( $\left.8^{\circ} 32^{\prime} 52.5^{\prime \prime} \mathrm{N} 76^{\circ} 34^{\prime} 23.7^{\prime \prime} \mathrm{W}\right)$ of the municipalities of Turbo y Necoclí, respectively. In these localities nine hamlets were selected, five in Alto de Mulatos and four in Las Changas based on ease of access and safety (i.e., minimal presence of armed groups). The main inclusion criterion to participate in the survey was to be head of the household and be able to understand and sign the informed consent. Due to safety concerns, individuals suspected of being affiliated with illegal armed groups were excluded from the study. ${ }^{1}$

\section{Sample size}

The sampling units were households in each hamlet and the unit of analysis was the information provided by the each head of household. A census of households was 
performed in each of the nine hamlets to obtain a sample frame; 461 households were registered in the census, 225 of which were located in areas with higher concentration of households connected by sidewalks and located close to the health center, while 236 were located at the periphery in areas with less concentration of households spread along access routes. A random finite proportional sampling was designed and a sample size of 208 households was estimated, with a 5\% error, 95\% confidence level and $41 \%$ of seroprevalence against rickettsias (LONDOÑO et al., 2017).

\section{Survey of Knowledge, Attitudes and Practices (KAP)}

The KAP questionnaire was adapted of a malaria survey from Turner et al. (2008) by the study team, which included anthropologists, local physicians, epidemiologists and health professionals. In addition, the research assistants, who are residents in the study area, contributed to the adjustment of the questionnaire. A total four assistants, two nurses and two previously trained individuals from the community carried out the pilot study with the participation of 3 to 4 people from Necoclí and Turbo. The anthropologist working in the field verified that residents of the area understood the terms included in the questionnaire. Aside from replacing the term "rickettsiosis" with "tick-fever", no major changes were necessary. The final questionnaire was administered to heads of households of randomly selected households between November 2015 and January 2016. The questionnaire had 32 items, 10 related to knowledge, 8 to attitudes, and 14 to practices (tables 3, 4 and 5).

\section{Semi-structured interviews}

The purpose of the semi-structured face-to-face interviews was to obtain information about knowledge and perceptions related to fevers, tick fever, and the therapeutic management of fevers. The interviews took place between May and August 2016. The interviews were conducted by field researcher anthropologist. All interviews were audio recorded and transcribed verbatim. The field researcher also kept a journal of observations.

Parts of the interviews focused on the use of land, changes in landscape, and interactions between humans and wild animals. Snowball sampling was used to choose key informants. Nine individuals from the locality of Alto de Mulatos were interviewed and only one individual from Las Changas (due to the armed conflict 
between the Colombian National Army and illegal armed groups operating in the region). Table 1 presents the sociodemographic characteristics of interviewees.

A thematic analysis of the transcripts was done by two members of the research team. Codes were manually developed independently and cross-verified. After further joint coding, themes related to information about fevers, tick fever, control of fevers, knowledge about rickettsiosis, land use, changes in landscape, and interactions between people, domestic animals and wild animals were identified

Table 1. Sociodemographic characteristics of interviewees from rural areas of Urabá, Antioquia, 2016

\begin{tabular}{|c|c|c|c|c|c|}
\hline & $\begin{array}{c}\text { Age } \\
\text { (years) }\end{array}$ & Sex & Occupation & $\begin{array}{c}\text { Time of } \\
\text { residence in the } \\
\text { area (years) }\end{array}$ & Residence \\
\hline Interviewee 1 & 28 & Female & $\begin{array}{c}\text { University } \\
\text { student }\end{array}$ & 28 & Alto de Mulatos \\
\hline Interviewee 2 & 63 & Male & Farmer & 36 & Alto de Mulatos \\
\hline Interviewee 3 & 62 & Male & Farmer & 13 & Alto de Mulatos \\
\hline Interviewee 4 & 42 & Female & Nurse aid & 4 & Alto de Mulatos \\
\hline Interviewee 5 & 64 & Male & Farmer & 18 & Alto de Mulatos \\
\hline Interviewee 6 & 54 & Male & Farmer & 54 & Alto de Mulatos \\
\hline Interviewee 7 & 53 & Female & $\begin{array}{c}\text { Pharmacy } \\
\text { assistant }\end{array}$ & 10 & Alto de Mulatos \\
\hline Interviewee 8 & - & Male & Farmer & 20 & Alto de Mulatos \\
\hline Interviewee 9 & 65 & Female & Home maker & - & Las Changas \\
\hline
\end{tabular}

Source: Interview about knowledge and perceptions related to tick fever in Las Changas and Alto de Mulatos, Urabá region, 2016.

\section{Statistical Analysis}

Relative and absolute frequencies were reported for each of the items of the KAP questionnaire. A descriptive analysis was done for sociodemographic variables of those surveyed, with a median and interquartile estimation for quantitative variables and frequency estimation for dichotomous and polychotomous variables. SAS 14.2 was used for the statistical analyses. 


\section{Ethics}

All study procedures had the approval of the Ethics Committee of the Facultad Nacional de Salud Pública, Universidad de Antioquia. As well, study participants signed an informed consent form and did not receive financial contribution for their participation.

\section{Results}

\section{Sociodemographic caracterization of surveyees}

A total of 246 individuals from different households located in 9 hamlets of Las Changas and Alto de Mulatos. Of those surveyed, 58.1\% were from Las Changas and 41.9\%(103/246) from Alto de Mulatos, 57.4\% (140/244) had at least partial elementary school education and $29.9 \%(73 / 244)$ had at least some secondary education. Only 3.4\% (8/244) had some post-secondary education; $75.4 \%$ (184/244) of participants were women. The median age was 43.9 years (IQR:34.1-55.8) and median time living in the area 15 years (IQR:7.0-29.0) (Table 2). Two individuals did not provide sociodemographic information.

Table 2. Sociodemographic characteristics of respondents from Alto de Mulatos and Las Changas, 2016

\section{Sociodemographic Characteristics}

Sex

Female

\section{Ethnia}

Mestizo

Caucasian

Afro

Indigenous

\section{$\%(n=244)$}

\section{4}

92.2

6.2

0.8

0.8

continua... 


\section{Education}

Elementary school complete

Elementary school incomplete

Secondary school complete

Secondary incomplete

Technical postsecondary

Tecnology postsecondary

University

No formal education

\section{Ocupation}

Outside

Inside

Time of residence in area, years (Median and IQR)

Source: Survey about knowledge, attitudes and practices related to tick fever in Las Changas and Alto de Mulatos, Urabá region, 2016.

\section{Knowledge about febrile syndromes and "tick fever"}

Among those surveyed, 86.6\% mentioned having heard about "tick fever". The vast majority, $97.2 \%$, considered "tick fever" to be a problem; $90.2 \%$ thought that the regional medical center should prevent this disease.

In relation to beliefs about the transmission of "tick fever", $8.1 \%$ of those surveyed thought that it is transmitted by rat bites, $15.5 \%$ by contaminated foods, and $32.9 \%$ by mosquito bites (graph 1). 
Graph 1. Survey responses to the question: How is tick fever transmitted?
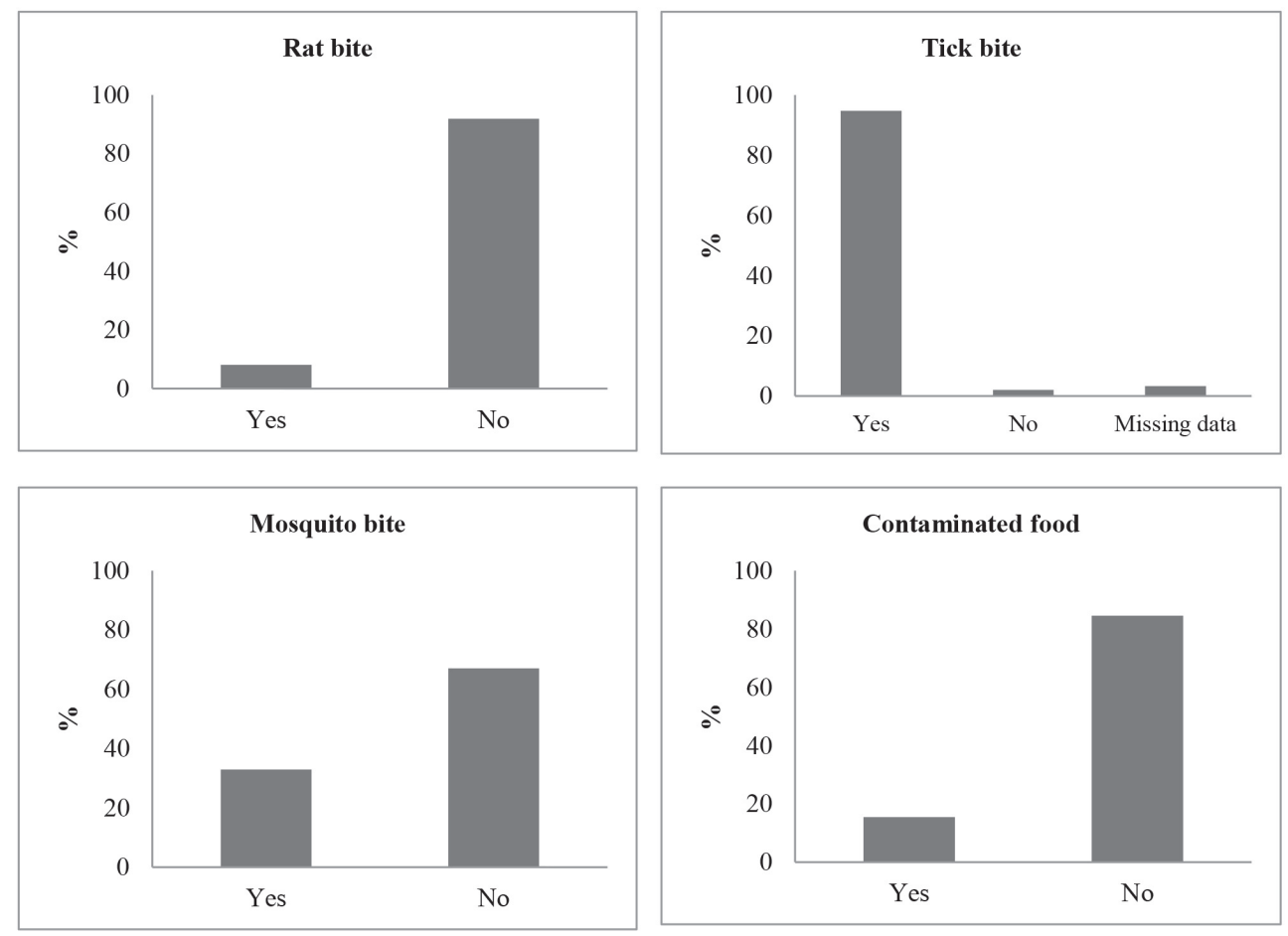

Source: Survey about knowledge, attitudes and practices related to tick fever in Las Changas and Alto de Mulatos, Urabá region, 2016

In relation to clinical signs and symptoms of "tick fever", $97.9 \%$ thought that it produced fever, $89.4 \%$ headaches, $91.1 \%$ muscle pain, $89.0 \%$ chills, $80.5 \%$ general tiredness and weakness, and $44.3 \%$ vomiting and diarrhea (table 3 ).

In relation to knowledge about cases of "tick fever" that happened in 2006 and 2008 in both localities, only $8.9 \%$ of those surveyed knew that people had died due to this disease. The majority indicated they had never been tested for "tick fever" (88.2\%). Of those that indicated being tested, 96.6\% (28/29) said that it was done with a blood test, $6.9 \%(2 / 29)$ with urine test, and $3.5 \%(1 / 29)$ by an eye exam; $91.5 \%$ indicated that ticks can transmit disease and $99.6 \%$ stated that ticks affect both domestic animals and people (table 3). 
Table 3. Knowledge related to febrile syndromes and tick fever in people living in Las Changas and Alto de Mulatos, 2016

\begin{tabular}{|c|c|}
\hline Survey & $\begin{array}{c}\% \\
(n=246)\end{array}$ \\
\hline 1. Have you heard about tick fever? & 86.9 \\
\hline Yes & 13.4 \\
\hline \multicolumn{2}{|l|}{ No } \\
\hline \multicolumn{2}{|l|}{ 2. Do you consider tick fever a problem? } \\
\hline Yes & 97.2 \\
\hline No & 2.4 \\
\hline Don't know & 0.4 \\
\hline \multicolumn{2}{|l|}{ 3. Who should prevent tick fever? } \\
\hline \multicolumn{2}{|l|}{ Family } \\
\hline Yes & 30.9 \\
\hline No & 69.1 \\
\hline \multicolumn{2}{|l|}{ Government } \\
\hline Yes & 45.9 \\
\hline No & 54.1 \\
\hline \multicolumn{2}{|l|}{ Community } \\
\hline Yes & 26.8 \\
\hline No & 73.2 \\
\hline \multicolumn{2}{|l|}{ Medical center of the region } \\
\hline Yes & 90.2 \\
\hline No & 9.8 \\
\hline Don't know & 1.6 \\
\hline \multicolumn{2}{|l|}{ 4. How do you think tick fever hits you? } \\
\hline \multicolumn{2}{|l|}{ Water } \\
\hline Yes & 0.4 \\
\hline No & 99.6 \\
\hline
\end{tabular}




\begin{tabular}{|c|c|}
\hline Survey & $\begin{array}{c}\% \\
(n=246)\end{array}$ \\
\hline \multicolumn{2}{|l|}{ Air } \\
\hline Yes & 0.4 \\
\hline No & 99.6 \\
\hline \multicolumn{2}{|l|}{ Person to person } \\
\hline Yes & 3.3 \\
\hline No & 96.7 \\
\hline \multicolumn{2}{|l|}{ Rat bite } \\
\hline Yes & 8.1 \\
\hline No & 91.9 \\
\hline \multicolumn{2}{|l|}{ Contaminated food } \\
\hline Yes & 15.5 \\
\hline No & 84.5 \\
\hline \multicolumn{2}{|l|}{ Mosquito bite } \\
\hline Yes & 32.9 \\
\hline No & 67.1 \\
\hline \multicolumn{2}{|l|}{ Tick bite } \\
\hline Yes & 94.7 \\
\hline No & 2.0 \\
\hline Missing data & 3.3 \\
\hline Don't know & 1.6 \\
\hline \multicolumn{2}{|l|}{ 5. What discomfort does tick fever cause? } \\
\hline \multicolumn{2}{|l|}{ Fever } \\
\hline Yes & 98.0 \\
\hline No & 2.0 \\
\hline \multicolumn{2}{|l|}{ Headache } \\
\hline Yes & 89.4 \\
\hline No & 10.6 \\
\hline
\end{tabular}




\begin{tabular}{cc}
\hline Survey & $\%$ \\
$(\mathrm{n}=246)$ \\
\hline
\end{tabular}

Muscle and bone pain

Yes

91.1

No

Chills

Yes

89.0

No

Weakness and fatigue

Yes

80.5

No

Vomits and diarrhea

Yes

No

Don't know

6. How is tick fever cured?

Taking the pills provided by mosquito control personnel

Yes

No

Taking aspirin

Yes

No

97.2

Taking medicine prescribed by the pharmacy

Yes

No

Attending the health center

Yes

No

21.1

continua... 


\begin{tabular}{cc}
\hline Survey & $\%$ \\
$(\mathrm{n}=246)$ \\
\hline
\end{tabular}

Attending a shaman or healer

Yes 0

No 100

Don't know

7. Has any member of the community died from tick fever?

Yes

No

8. How many people have died from tick fever in their community?

Boys (0-17 years) $\leq 2$

Girls (0-17 years) 2

Young adults (18-40 years) $\leq 4$

$\begin{array}{ll}\text { Older adults (older than } 40 \text { years) } & 0\end{array}$

9. Did you have any test to see if you have tick fever?

Yes

No

10. What tests did you do?

Urine sample $(\mathrm{N}=29)$

Yes

No

Blood sample $(\mathrm{N}=29)$

Yes

No

Physical test $(\mathrm{N}=29)$

Yes

No

Vision test $(\mathrm{N}=29)$

Yes

No

96.5

Source: Survey about knowledge, attitudes and practices related to tick fever in Las Changas and Alto de Mulatos, Urabá region, 2016 


\section{Attitudes toward febrile syndromes}

Of those surveyed, $76.4 \%$ stated that when they had febrile symptoms they went to a health centre; $32.1 \%$ mentioned going to a pharmacy when they had fever, and $29.3 \%$ said they went to the municipal hospital. As well, $93.5 \%$ of those surveyed stated that they took the medications that the health centres prescribed for fever; $99.2 \%$ indicated that they were in favor of fumigation of their homes (graph 2 and table 4).

Graph 2. Survey responses to the question: Where do you do when you have fever?
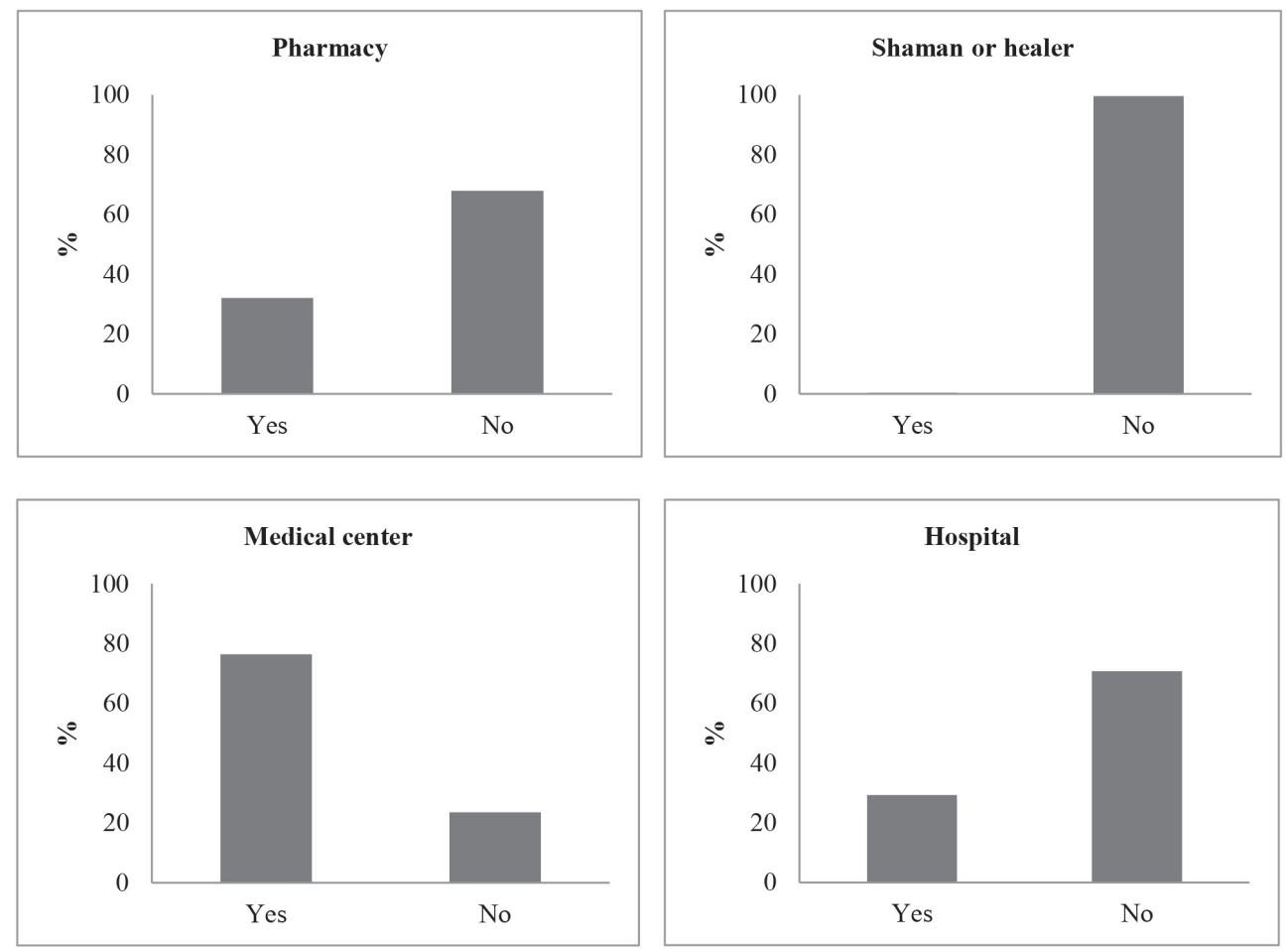

Source: Survey about knowledge, attitudes and practices related to tick fever in Las Changas and Alto de Mulatos, Urabá region, 2016 
Table 4. Attitudes related to febrile syndromes and tick fever in people living in Las Changas and Alto de Mulatos, 2016

\begin{tabular}{cc}
\hline Survey & $\%$ \\
$(\mathrm{n}=246)$ \\
\hline
\end{tabular}

1. Where do you go when you have fever?

Farmacy

Yes

No

Shaman or healer

Yes

No

99.6

Medical center

Yes

76.4

No

Hospital

Yes

No

70.7

2. Do you take the pills against the tick fever that the health staff gives you? Yes

No

3. Do you agree with the insecticide spraying in your home? Yes

No

4. Do you agree with the visit of health personnel to attend a fever? Yes

No

5. Are there people in the community who cure tick fever and other diseases? Yes

No

continua... 


\section{Survey}

$(n=246)$

6. How do you take care not to get sick with tick fever?

Filling the puddles around your home with dirt or sand

Yes

No

Organizing clean-up days in the community

Yes

No

Using insect repellents

Yes

No

Personal protection (use of clothing that protects against stings,

long-sleeved shirt and long pants)

Yes

No

Spraying the house with poison (spray)

Yes

No

Don't know

7. Do you think ticks are dangerous?

Yes

97.2

No

8. What can ticks do to you?
Absolutly nothing
Yes
0.41
No
99.6
continua... 


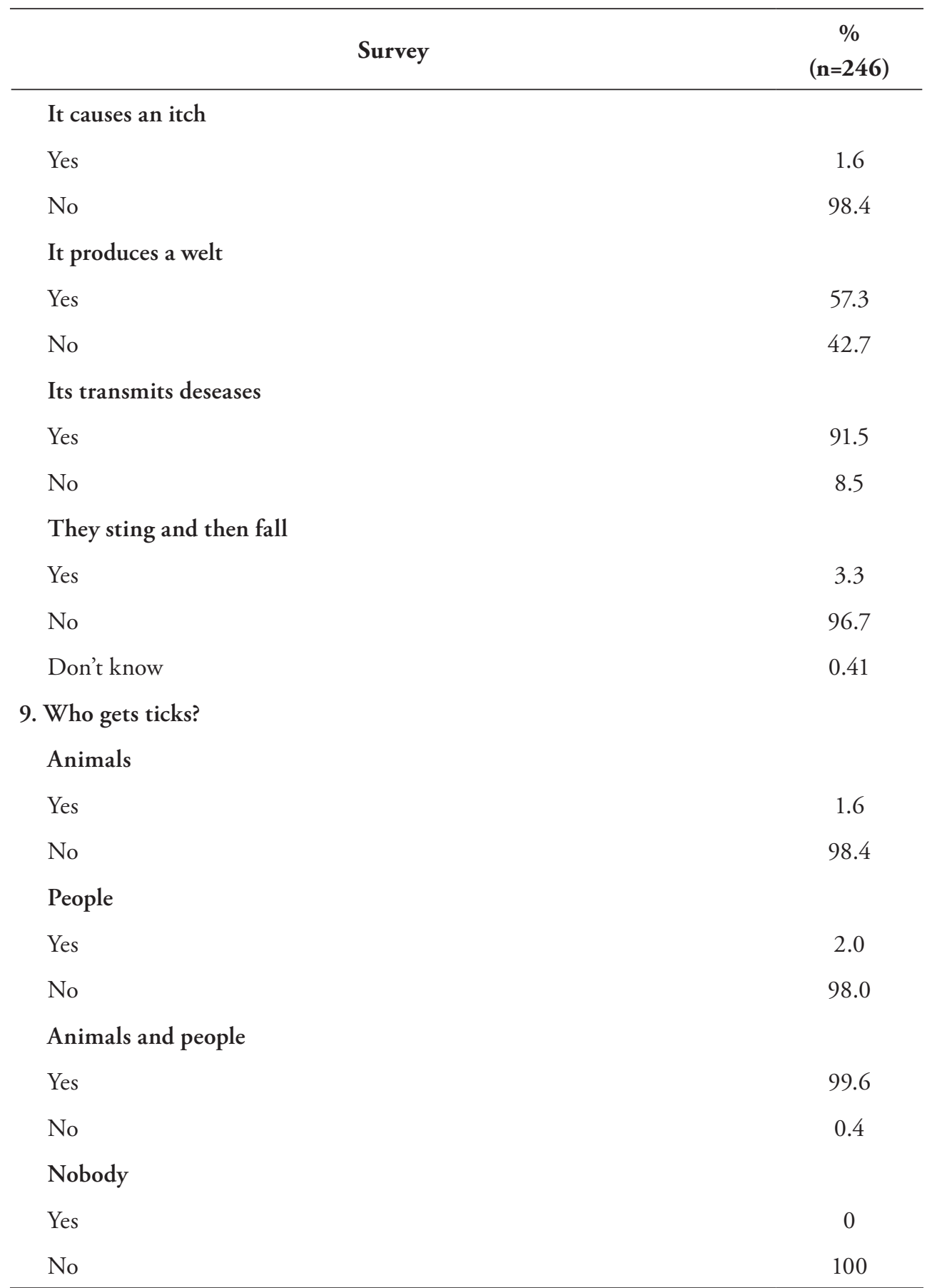

Source: Survey about knowledge, attitudes and practices related to tick fever in Las Changas and Alto de Mulatos, Urabá region, 2016 


\section{Sociocultural practices associated to appearance of tick fever}

People from the study area have practices that increase and decrease the probability of transmission of tick fever; $17.5 \%$ of those surveyed use some type of insect repellent; $72.8 \%$ use long arm shirts; $28.5 \%$ use light colored clothing; and 51.2\% check themselves when coming from the fields if they are infested by ticks (graph 3).

Other practices that were considered to assess the probability of transmission of tick fever were if individuals used forests close to urban areas to cultivate and if they used measures to control the infestation of rodents in their homes. Also, 58.1\% of those surveyed stated that they use nearby forests to cultivate, and $57.7 \%$ stated that they took measures to control rodents in their homes (graph 3). Furthermore, 36.6\% of interviewees that had pet dogs would bathe them to control the infestation of fleas or ticks. Only $4.5 \%$ of those surveyed indicated that they hunted wild animals (table 5).

\section{Graph 3. Questions related to practices that protect against or increase the risk of} tick fever
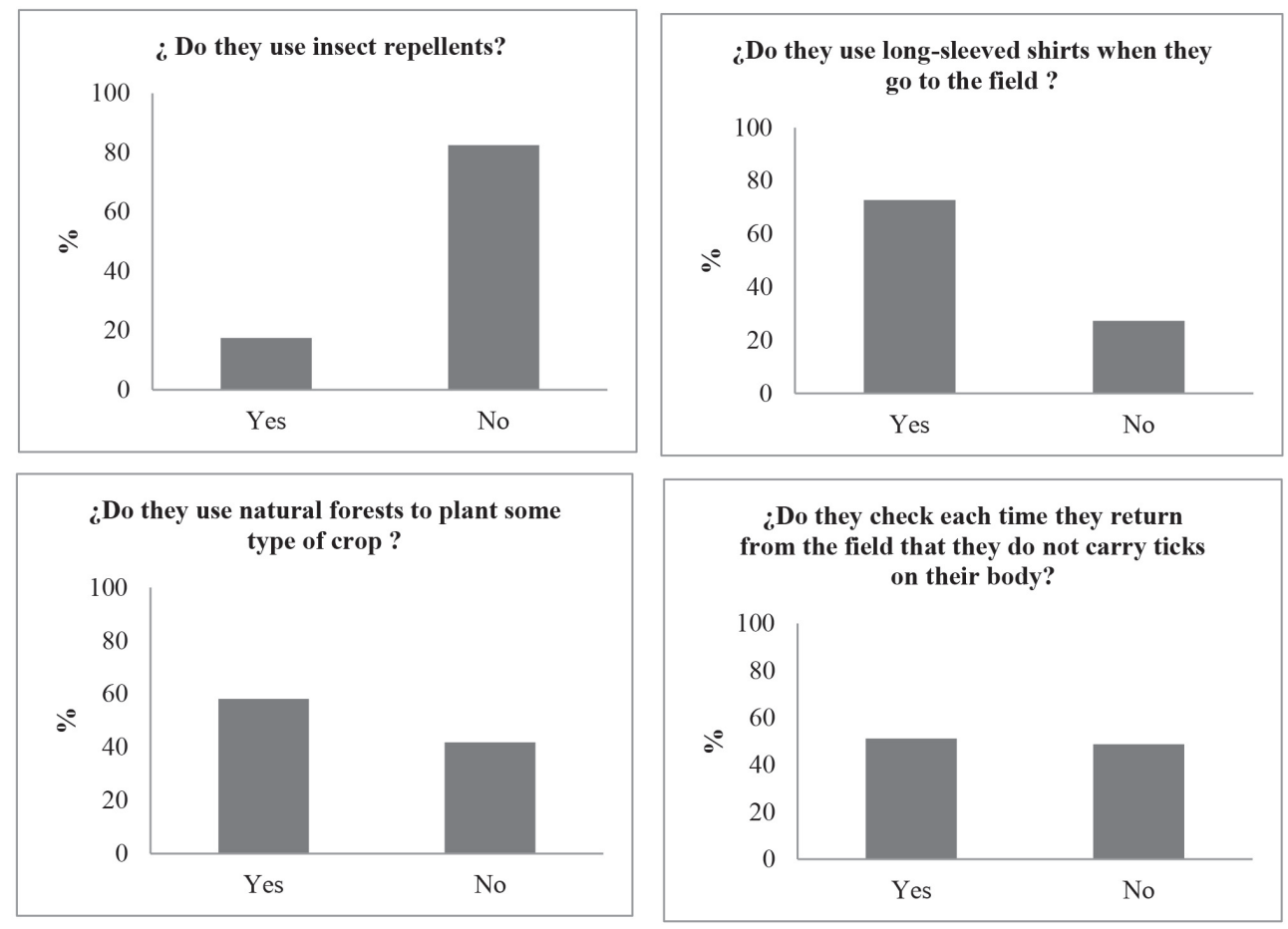

Source: Survey about knowledge, attitudes and practices related to tick fever in Las Changas and Alto de Mulatos, Urabá region, 2016 
Table 5. Practices related to febrile syndromes and tick fever in people living in Las Changas and Alto de Mulatos, 2016

\section{Survey}

1. Do you keep the channels and ditches clean around your house?

Yes

No

2. Do you use insecticides around your house?

Yes

No

3. Do you use insect repellents?

Yes

No

4. Do you bathe your dogs with flea and tick poison?

Yes

No

Don't know

5. How often do your pets bathe with flea and tick poison?

Weeks $(n=48)$

1 week 64.6

2 weeks 33.3

3 weeks

Months $(\mathrm{n}=40)$

1 month

2 months

3 months

6 months

Year $(n=2)$

1 year 
6. Do you wear white or light clothing when you work outdoors?

Yes

No

7. Do you wear long-sleeved shirts when you go work outdoors?

Yes

No

8. Do you check that you don't have any ticks on your body after working outdoors?

Yes

No

9. Do you take care of the environment around you?

Yes

No

10. Do you plant crops in natural forests?

Yes

No

11. Do you use any measure of protection against rodents?

Yes

No

12. Which protection measure?

Poison

Yes

No

Other

13. Do you hunt forest animals?

Yes

No

continua... 


\begin{tabular}{cc}
\hline Survey & $\%$ \\
& $(\mathrm{n}=246)$ \\
\hline
\end{tabular}

14. Why do you hunt?

Eating $(n=11)$

Yes

No

Sport $(\mathrm{n}=11)$

Yes

No

To defend domestic animals $(n=11)$

Yes

No

Sell $(\mathrm{N}=11)$

Yes

No

Source: Survey about knowledge, attitudes and practices related to tick fever in Las Changas and Alto de Mulatos, Urabá region, 2016

\section{Description of narrations related to febrile syndromes and tick fever}

The narrations of those interviewed suggested that tick fever is more associated as something that is bothersome, more than to the fact that the tick bite can be the cause of transmission of a potentially lethal agent. As well, given that it is an illness that has as differential diagnosis other entities that are more frequent in the area, such as dengue and malaria, tick fever or rickettsioses was essentially unknown by those interviewed. It is also likely that, as it happens among health professionals, it is confused with other entities.

Q: ¿Do you believe in tick fever?

A: I believe in it. ...that can be positive, because when sometimes a tick bites you, I tell you that it gives you fever ... (Interview. Male, age 64, Alto de Mulatos, Turbo, 2016).

The narration of a woman who lost two brothers in the rickettsiosis outbreak of 2008 in Alto de Mulatos, shows how this fever is not identified as such neither in 
the community or at the hospitals. This is particularly problematic given the severe clinical cases that result from an infection from Rickettsia rickettsii, and the urgent need of antibiotic treatment that is required. Those people have died because of this disease due to lack of knowledge of an entity of confirmed presence in the region by health centers and regional hospital personnel is of serious concern.

My brothers died quickly, it was unexpected for us...they had symptoms similar to Dengue and...we thought it was Dengue or Malaria because in this tropical area these diseases are common and since they are easy treat, if we can say that, they receive immediate treatment. However, my brothers on the third day in the hospital became very sick and died. (Interview. Female, age 28. Alto de Mulatos, Turbo, 2016).

The interviews suggested that people do not recall the outbreaks of rickettsiosis in the area. It would seem that the information provided by government agencies was forgotten. In fact, some interviewees that believed in "tick fever" could not refer to any single person that had died of this disease. Knowledge about the disease seemed to essentially reside in families that had experienced fatal cases. During the 2008 outbreak, aside from community members, military personnel were affected. The statement that follows mentions it.

During that time many people were sick, as I said there was Malaria, there was Dengue...there were others, I know at least of one soldier, a military guy that died and some children...but I don't know exactly how many died with the same symptoms. (Interview. Female, age 28. Alto de Mulatos, Turbo, 2016).

Febrile syndrome was perceived by interviewees as due to flu, malaria, parasitoids from nematodes, dengue, more recently chikungunya, and "evil eye." These febrile syndromes are usually treated with medicinal plants or allopathic medicine. In general, people are treated with acetaminophen, ibuprofen, aspirin and antibiotics sold without prescriptions. In relation to plants, interviewees mentioned oregano and melissa leafs, as a way to reduce fever. As well, they may use oak buds, "paico", balsam and creole lemon. For infections they may use dandelion, stiletto tail, and rabbit ear. Other methods less frequently used are papaya leafs, for instance for children's fever where the sugar is added to the leaf that is then tied to the feet.

In relation to allopathic medicine, according to the interviewees people tend to self-medicate with what is most frequently prescribed in rural health centers and the municipal hospital. As stated by a study participant, with the "the magic pill of acetaminophen and naproxen". Concerning care provided at health centers, 
interviewees seemed to be unhappy about the lack of clarity in diagnoses and repeated treatments provided. This is how a person affected by several febrile syndromes describes going to the health center or regional hospital.

The main and immediate thing we state is that we are relatives of a case: "Provide us care"... One has the to fight... that... they do tests, because sometimes they say: "No, you have normal fever" and they give you a prescription and send you home. But when there is a fever of more than one day and it continues...we straight forward say, please do the tests because, my mother says: "Here they let my two sons die, you will not let this one die." (Interview. Female, age 28. Alto de Mulatos, Turbo, 2016).

Another important aspect in the region for the study of rickettsioses is the change in land use. This was in part due to the migration of people from outside of the locality related to displacements caused by the war between illegal armed groups.

Well, at the time it was very cold, it has changed quite a lot, eight or ten years, but I think that the reason was the clearance of the jungle. (Interview. Male, age 62. Alto de Mulatos, Turbo, 2016).

Before there was lots of stub, bush, jungle there was a lot; imagine that you don't see it anymore, people have cut to plant and grow pasturage. (Interview. Male, age 63. Alto de Mulatos, Turbo, 2016).

Migrants started to indiscriminately exploit the land, clearing the forest to harvest wood and start raising cattle. People started to buy or expropriate the land of those that were displaced, leading to a radical change in the use of the land in the region.

They would buy the land from so and so, then this person would clear it and grow pasturage for cattle, so agriculture was in retreat because the lands were now in hands of those that do not like agriculture...that is, corn, rice... (Interview. Male, age 62. Alto de Mulatos, Turbo, 2016).

Another important aspect that should be considered in relation to changes in land use in this region is that it would seem that the change was promoted by governmental agencies that provided resources of livestock for people that had parcels of land or land with pasturage. As explained by an interviewee, this process ended in a massive cutting of forests.

When trees were not considered important because the objective was to cut them for clearance, for pasturage, and thus receive assistance from an agency called INCORA; those that had paddocks, pasturage, they receive help for cattle. Those people are motived to créate pasturage, to cut trees. (Interview. Male, age 54. Alto de Mulatos, Turbo, 2016). 
As well, it would seem that in the region some people do not clear the forest for agriculture or pasturage due to lack of funding. Some of the interviews suggested that people with large extensions of land do no clear the forest, not because they think that is the right thing to do, but because they do not have the resources to do so.

Q: Who owns the lands of those who have not cleared the forest?

A: Poor peasants that don't have with what to do it, with what to improve it and have a little bit of land. There is a man who has 200 hectares of land, and at the most he plants rice and some corn. (Interview. Male, age 63. Alto de Mulatos, Turbo, 2016).

The timing between changes in the use of the land in the region and the outbreaks of "tick fever" is interesting. Is it plausible that these changes were related to the presentation of the disease? It is well known that after deforestation of areas species of mammals are impacted, tending to increase the convergence between vectors, intermediary hosts and humans.

When asked about the relation between wild fauna and inhabitants of the area, some people mentioned having respect for them, even when taking into account losses that their harvest suffers due to these animals. However, according to interviewees other individuals do not allow any type of wild animals close to their homes or crops, which they hunt not for food but as protection against them.

I think that in the harvest the parrot, the "cheja", the fox, the "tatabra" accompany us. ¿What to do? plant for them to also eat because I believe that it would not be good to take an animal and kill it ...(Interview. Male, age 62. Alto de Mulatos, Turbo, 2016).

\section{Discussion}

In Villeta, Cundinamarca, region close to the capital of Colombia (Bogota), a study was conducted with communities that had been affected by outbreaks of rickettsiosis. The main objectives were to learn about risk perception and knowledge of community members about this disease. The study discussed the need to utilize appropriate terminology with the population of Villeta to identify rickettsiosis. The regional health centres and the Instituto Colombiano Agropecuario (ICA) agreed that the term most recognizable among the population would be "tick fever" (SUÁREZ et al., 2008).

Our study showed that interviewees knew about "tick fever," however the findings from the KAP survey and the interviews suggested contradictory responses. This may be related to the name given in the Villeta study (SUÁREZ et al., 2008). For 
instance, the region's health center staff person stated that she had no knowledge of the illness and only heard about it when the rodents' study started in the area. Similar results were found in the Villeta region, where health staff and community members did not know about these entities. As such, they were invisible and only considered in specialized biomedical centers (SUÁREZ et al., 2008).

According to our KAP survey results, people in the area recognize the signs and clinical symptoms of a febrile syndrome. In the biomedical field, a clinical algorithm that can identify or clinically diagnose several entities that cause disease in tropical regions has been a priority (CORTÉS et al., 2016). A study done in the municipal hospitals of Urabá, Antioquia, found that the clinical signs for entities such as dengue, leptospirosis and rickettsiosis are non-specific. Consequently, this should be taken into consideration when differential diagnosis are done in this region(ARROYAVE et al., 2013).

It was observed in rural communities that the outbreaks that occurred in 2006 and 2008 seemed to have been forgotten, only remembered by those directly affected. Even so, the narrations of people that had family members that died suggested that they were no very sure what disease was the cause. In some cases they went from being diagnosed with severe dengue and others with "rat fever" which what leptospirosis is commonly called.

"Natural" treatments for fever are utilized before the symptoms become severe, at which point they go to the pharmacy, or to the regional health center or municipal hospital. The Villeta, Cundinamarca study showed that community members mentioned that when they had symptoms of fever and general aches, they would go to the pharmacy to buy what is called "the marriage" that are antibiotics in combination with some analgesic (SUÁREZ et al., 2008). During the 2008 outbreak in Alto de Mulatos, several cases of rickettsiosis that were accepted in the municipal hospitals of the Urabá region had been treated with "paico water", a beverage that community members state cures fever (GIRALDO et al., 2008).

The fact that community members are receptive to fumigating around and inside their homes may be partially explained by the ongoing work of groups seeking to control the population of mosquitos in the area responsible for the transmission of dengue and malaria. These measures, according to the Ministry of Health of Colombia, must be taken every 3 to 6 months in endemic areas with 
products such as pyrethroids and organophosphorus, products that also control tick infestation in households (LÓPEZ et al., 2006).

The United States Center for Disease Control (CDC) recommends that people who work outdoors, such as farmers and other similar jobs, should take measures to reduce the risk of tick infestation including the use of light colored clothing and long sleeve (BIGGS et al., 2016). In the study region, people tend to use these protective measures, although it is not clear if they use them to protect from ticks or from the sun.

The lack of knowledge about rickettsiosis among health professionals has also been noticed in other countries where the disease is endemic. It is of concern for epidemiological surveillance that unspecific cases are found that should not result in the death of patients (DE OLIVEIRA et al., 2016). This should also be of concern in Colombia, particularly in areas where the disease has been confirmed, and in areas where there are conditions that may favor the presentation of cases of febrile syndromes.

Rickettsioses, being a disease that does not have epidemiological surveillance in Colombia and that has caused the death of several people because of lack of differential diagnosis in hospitals, is a febrile syndrome that should be managed promptly. This is needed to drastically decrease the high rates of lethality of the disease, especially when infected with the species $R$. rickettsii (BIGGS et al., 2016).

In the United States, since the 1960s there has been concern related to the changes in land use and its association with cases of rickettsiosis (NEWHOUSE et al., 1979). The constant alteration of the environment by humans has broken the balance in fauna and flora of specific areas. In Brazil, the areas with higher risk of rickettsia infections are precisely in the areas where rain forests have been fragmented. This fragmentation has reduced the number of wild mammals, with the consequence that ticks species that commonly infest these animals, start infesting domestic animals such as dogs (SCINACHI et al., 2017).

Based on what we heard from interviews, incentives from the Instituto Colombiano de la Reforma Agraria (Colombian Institute for Rural Reform) related to supporting low-income peasants to acquire livestock lands. These processes, in part, seem to have drastically changed the environment of the study localities and could have been one of the determinants of the 2006 and 2008 outbreaks. 
Several hypotheses have been posed in relation to the diversity of wild animals and the presentation of infectious diseases. More diversity is linked with decreased risk of infectious disease, especially due to the "dilution effect" that may be present in areas of high diversity (OGRZEWALSKA et al., 2012; ESTRADA-PEÑA et al., 2014). The interviews with people from Alto de Mulatos suggested a radical change in the diversity of animal species in the area, including scarcity of mammal species that were common in the area. According to those interviewed peccaries, "guaguas", some venison and wild carnivore mammals have been almost eliminated in the area.

The interviews conducted in Alto de Mulatos helped us describe certain processes linked to febrile syndromes in the area. The main limitation of the study was not being able to explore more in-depth the issue due to not being able to have a more systematic interview process to better assess data saturation. Some findings are presented with caution and are not expected to be generalized to the entire population. Nonetheless, narrations from people impacted by "tick fever" are important to consider to better understand the context when conducting biomedical interventions and research.

The name used in this study "tick fever" was explored in the interviews and surveys done in the region. However, we cannot ignore that there may be similar frequent disease in domestic animals such as erhlichiosis or anaplasmosis, that may mask the meaning of these diseases in humans and as such community members may associate them with an entity that may produce febrile syndromes.

\section{Conclusions}

It is necessary to conduct more studies in the area to understand more in-depth the social cultural processes here described. The study findings are a starting point from where to implement education programs in communities that have been affected by "tick fever". Health education is of crucial importance to prevent the more serious cases of the disease.

The study provided evidence of suggested low level of knowledge about "tick fever" and a general lack of recollection (less than 10\%) of outbreaks that had occurred in the area. These outbreaks would have caused alarm due to deaths that occurred, but did not remain in the memory of people. It is an approximation to the sociocultural conditions of febrile syndromes in rural areas of Urabá, Antioquia that 
have been impacted by several outbreaks of disease, among them rickettsioses. "Tick fever" refers to a disease that causes the same symptoms as other more frequent disease in the area, such as dengue y malaria. ${ }^{2}$

\section{Acknowledgments}

We are thankful to the research groups Salud y Ambiente and Epidemiología from Facultad Nacional de Salud Pública of the Universidad de Antioquia for their logistic support to conduct this study. Finally, we are grateful to the anthropologists Elias Sevilla Casas, for his advice in the field study, and Karen Mena, for her assistance in conducting the interviews in Las Changas and Alto de Mulatos.

\section{References}

ACOSTA, J. et al. Brote de rickettsiosis en Necoclí, Antioquia, febrero- marzo de 2006. Inf Quinc Epidemiol Nac, v. 11, n. 12, p. 177-192, 2006.

ARBOLEDA, M. et al. Perfil clínico y de laboratorio de los pacientes con malaria por Plasmodium vivax, hospitalizados en Apartadó, Colombia. Biomédica: Revista del Instituto Nacional de Salud, v. 32, p. 58-67, 2012.

ARROYAVE, E. et al. Etiología y caracterización epidemiológica del síndrome febril no palúdico en tres municipios del Urabá antioqueño, Colombia. Biomédica : Revista del Instituto Nacional de Salud, v. 33, n. 1, p. 99-107, 2013.

BIGGS, H. M. et al. Diagnosis and Management of tickborne rickettsial diseases: Rocky Mountain spotted Fever and other spotted fever group rickettsioses, ehrlichioses, and anaplasmosis - United States. Morbidity and Mortality Weekly Report. Recommendations and Reports, v. 65, n. 2, p. 1-44, 2016.

CORTÉS, J. A. et al. Enfoque clínico del síndrome febril agudo en Colombia. Infectio, v. 21, n. 1, 2016.

DE OLIVEIRA, S. V. et al. A fatal case of Brazilian spotted fever in a non-endemic area in Brazil: The importance of having health professionals who understand the disease and its areas of transmission. Revista da Sociedade Brasileira de Medicina Tropical, v. 49, n. 5, p. 653-655, 2016.

ESTRADA-PEÑA, A. et al. Effects of environmental change on zoonotic disease risk: an ecological primer. Trends in Parasitology, v. 30, n. 4, p. 205-214, abr. 2014.

GARCÍA PACHECO, O. E. et al. Estudio de brote febril hemorrágico en el corregimiento de Alto de Mulatos - Distrito Especial Portuario de Turbo, Antioquia, enero de 2008. Inf Quinc Epidemiol Nac, v. 13, n. 10, p. 145-160, 2008. 
GILLESPIE, J. J. et al. Rickettsia phylogenomics: unwinding the intricacies of obligate intracellular life. PloS one, v. 3, n. 4, p. 1-32, jan. 2008.

GIRALDO, M. et al. Estudio sindrome febril en el muncipio de Turbo, corregimiento Altos de Mulatos enero 2008. Boletín Información para la Acción, p. 1-5, 2008.

HIDALGO, M. et al. Outbreak of Rocky Mountain spotted fever in Córdoba, Colombia. Memórias do Instituto Oswaldo Cruz, v. 106, n. 1, p. 117-8, fev. 2011.

HIDALGO, M. et al. Rocky Mountain spotted fever, Colombia. Emerging infectious diseases, v. 13, n. 7, p. 1058-1060, 2007.

LONDOÑO, A. F. et al. Human prevalence for Rickettsias of the Spotted Fever Group (SFG) in endemic zones of Northwestern Colombia. Ticks and Tick-borne Diseases, v. 8, n. 4, p. 477-482, 2017.

LÓPEZ, J. G. ; et al. Gestión para la vigilancia entomológica y control de la transmisión de Malaria. Guía de Vigilancia Entomológica y Control de Malaria. Ministerio de la Protección Social, Republica de Colombia), p. 57-67, 2006.

NEWHOUSE, V. F. et al. Rocky Mountain spotted fever in Georgia, 1961-75: analysis of social and environmental factors affecting occurrence. Public health reports. Washington, D.C., v. 101, n. 4, p. 419-28, 1979.

OGRZEWALSKA, M. et al. Epidemiology of Brazilian spotted fever in the Atlantic Forest, state of São Paulo, Brazil. Parasitology, v. 139, n. 10, p. 1283-300, set. 2012.

PATIÑO, L.; AFANADOR, A.; PAUL, J. A spotted fever in Tobia, Colombia. 1937. The American Journal of Tropical Medicine, v. 17, p. 639-653, 1937.

QUINTERO, J. C. et al. Ecoepidemiología de la infección por rickettsias en roedores, ectoparásitos y humanos en el noroeste de Antioquia, Colombia. Biomédica : revista del Instituto Nacional de Salud, v. 33, n. Supl.1, p. 38-51, 2013.

RICKETTS, H. A micro-organism, wich apparently has a specific relationship to Rocky Mountain Spotted Fever. Journal of the American Association, v. 52, p. 379-380, 1909.

SCINACHI, C. A. et al. Association of the occurrence of Brazilian spotted fever and Atlantic rain forest fragmentation in the São Paulo metropolitan region, Brazil. Acta Tropica, v. 166, n. Feb, p. 225-233, 2017.

SUÁREZ, R. et al. Las rickettsias como agentes etiológicos de entidades febriles no diagnósticadas en Colombia. UNIANDES ed. Bogotá: Universidad de los Andes, 2008.

TURNER, R. et al. Encuesta sobre Conocimiento, Actitudes y Prácticas (CAP): Una herramienta para el abordaje intercultural de la malariaPrograma regional de acción y demostración de alternativas sostenibles para el control del vector de la malaria sin uso de DDT en América Central y México : programa regional salud de los pueblos indígenas de Las Américas. Panamá : Organización Panameri, 2008. 
VALBUENA, G. Fiebres que no deberían matar. Biomédica : revista del Instituto Nacional de Salud, v. 27, n. 3, p. 321-324, 2007.

VILLAR, L. A. et al. Epidemiological trends of dengue disease in Colombia (2000-2011): a systematic review. PLoS neglected tropical diseases, v. 9, n. 3, p. 1-16, mar. 2015.

YUSTI, D.; ARBOLEDA, M.; AGUDELO-FLÓREZ, P. Factores de riesgo sociales y ambientales relacionados con casos de leptospirosis de manejo ambulatorio y hospitalario, Turbo-Colombia. Biomédica : revista del Instituto Nacional de Salud, v. 33, n. 0, p. 117-129, 2012.

\section{Notes}

${ }^{1}$ This study was supported by Departamento Administrativo de Ciencia, Tecnología e Innovación (Colciencias) (Award: 111565741009 to Lisardo Osorio). The funders had no role in study design, data collection and analysis, decision to publish, or preparation of the manuscript. The authors have declared that no competing interests exist.

${ }^{2}$ J. C. Quintero V.: conceptualization, data curation, formal analysis, investigation, methodology, resources, supervision, visualization, writing-review and editing. J. Mignone: conceptualization, methodology, supervision, writing-review and editing. L. Osorio Q.: supervision, project administration, funding acquisition. C. Rojas A.: conceptualization, formal analysis, funding acquisition, supervision, writing-review and editing. 


\section{Resumo}

\section{Descrição sociocultural de sindromes febris em áreas rurais de Antioquia Urabá: um olhar sobre a "febre do carrapato"}

Introduçáo: Nos anos de 2006 e 2008, dois surtos letais de riquetsiose foram relatados em áreas rurais de Urabá, caracterizados pela falta de atenção imediata para o diagnóstico e tratamento com antibióticos.

Objetivo: Descrever aspectos socioculturais do conhecimento, atitudes e práticas de síndromes febris e "febre do carrapato" em áreas rurais de Antioquia, Urabá. Materiais e métodos: Realizou-se estudo exploratório, através de inquéritos sobre CAP (conhecimentos, atitudes e práticas) e entrevistas semiestruturadas sobre síndromes febris e "febre do carrapato", um nome que se refere às doenças das riquetsioses na área. Foram aplicados 246 inquéritos sobre a CAP foram realizadas aos chefes de agregados familiares e nove pessoas foram entrevistadas. Resultados: Observou-se que as pessoas tendem a identificar os sinais e sintomas clínicos característicos da dengue, malária, leptospirose e até riquetsiose. Um grande número de pessoas demonstra baixo conhecimento sobre "febre do carrapato" e indicou que ela é transmitida por mosquitos $(32,93 \%)$. Os entrevistados indicaram que as causas das diferentes síndromes febris se devem a parasitas intestinais, malária, dengue ou, como crença cultural, ao "mau olhado". A "febre do carrapato" o associa, pelo nome, com a mordida do carrapato. Além disso, o tratamento das síndromes febris referidas pelos entrevistados está intimamente relacionado ao uso comum da medicina ocidental e ao uso de "plantas medicinais". Conclusóes. É necessário ter programas de educação nessas áreas rurais para que essas entidades potencialmente letais tenham um tratamento efetivo e acessível.

> Palavras-chave: levantamento de CAP; entrevistas; riquetsiose; febre do carrapato. 